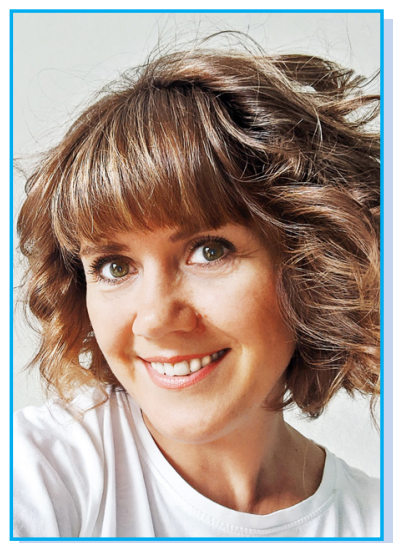

Оксана Джкенджеро - кандидат педагогічних наук, доцент, доцентка кафедри мов і методики їх викладання Національного університету «Чернігівський колегіум» імені Т.Г.Шевченка, м. Чернігів, Україна. Коло наукових інтересів: проблеми формування професійного мовлення у студентів нефілологічних спеціальностей; лінгвосинергетика; педагогічна творчість; організація самостійної роботи студентів; упровадження інтерактивних технологій навчання 3 метою розвитку комунікативних умінь у студентів. Волонтерка, популяризаторка української мови, спікерка освітніх івентів. Співавторка програми і тренерка інноваційних курсів підвищення кваліфікації вчителів «Окрилені», курсів удосконалення викладацької майстерності «Окрилені».

odzhen@gmail.com

https://orcid.org/0000-0002-9448-9999

Світлана Ющенко магістрантка факультету дошкільної, початкової освіти і мистецтва Національного університету «Чернігівський колегіум» імені Т.Г.Шевченка, учителька початкових класів Чернігівської загальноосвітньої школи I-ІІІ ступенів №3, м. Чернігів, Україна.

Коло наукових інтересів: формування мовленнєвої компетентності молодших школярів; інтерактивні методи навчання на уроках української мови; особиста творчість; популяризація української мови серед учнів початкової школи та їхніх батьків.

svitlanausenko155@gmail.com

https://orcid.org/0000-0002-8522-821X

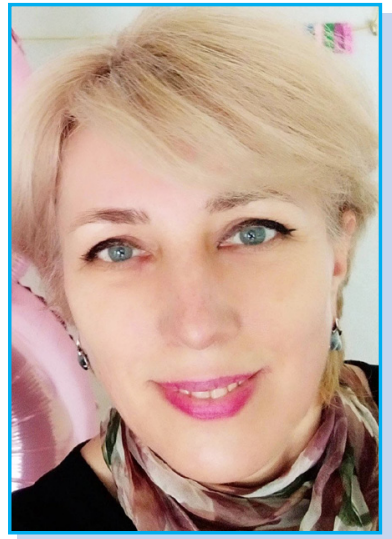

УДК 378. 147. 091.3:808.503: [373.3.091.12.011.3-051 https://doi.org/10.32405/2411-1317-2021-3-86-92

\title{
ВИКОРИСТАННЯ ТЕХНОЛОГІЙ ОПРАЦЮВАННЯ ДИСКУСІЙНИХ ПИТАНЬ У ПІДГОТОВЦІ МАЙБУТНІХ УЧИТЕЛІВ ПОЧАТКОВОЇ ШКОЛИ
}

У статті розглядається проблема застосування технологій опрацювання дискусійних питань та їх різновидів на уроках у початкових класах у процесі підготовки майбутніх учителів початкової школи, висвітлено етапи організації дискусії та роль педагогів у ній. Проаналізовано основні методи опрацювання дискусійних питань, які актуально використовувати під час проведення уроків у початкових класах. Встановлено, що освітнє середовище потребує вчителя, спроможного відходити від традиційних форм і методів роботи з учнями і водночас сприймати новий педагогічний досвід, нові технології, форми і методи роботи у своїй професійній діяльності. Розкрито організаційно-педагогічні умови, спрямовані на забезпечення підготовки майбутніх учителів до застосування інтерактивних технологій, зокрема технологій опрацювання дискусійних питань.

Ключові слова: спілкування; дискусія; інтерактивні технології; форми дискусії; методи; початкові класи. 
Постановка проблеми в загальному вигляді та її зв’язок з важливими науковими та практичними завданнями. Сучасному етапу розвитку освітньої галузі характерний пошук нових форм, методів і засобів навчання молодого покоління. Традиційне навчання дедалі частіше витісняється застосуванням інноваційних, експериментальних технологій. Не втрачають актуальності як у школі, так і у вищих навчальних закладах популярні у XXI столітті інтерактивні технології. Проте їх використання в навчальному процесі має нерегулярний характер. Аби повною мірою застосовувати інтеракцію у своїй діяльності, педагогам часто бракує розуміння змісту самих інтерактивних методик, способів організації взаємодії учнів і студентів, принципів добору того чи іншого інтерактивного методу для конкретної дисципліни чи теми. Труднощі виникають і у зв’язку з бажанням поєднати інтеракцію з традиційними для вищої школи формами заняття - лекцією, семінаром, практичним заняттям.

Перед вищими педагогічними закладами постає проблема методичної підготовки вчителів з новою прадигмою мислення, готових ризикувати, експериментувати, нешаблонно мислити, застосовувати у своїй практичній діяльності інноваційні методики. У зв'язку з цим актуальним вважаємо використання інтерактивних технологій, зокрема технологій опрацювання дискусійних питань, у практиці підготовки майбутніх учителів початкової школи.

Аналіз останніх досліджень і публікацій з проблеми. Починаючи з 30- х років XX ст., коли видатний швейцарський психолог Ж. Піаже довів, що завдяки механізму дискусій з однолітками, а також із старшими й молодшими дітьми дитина позбувається рис егоцентричного мислення, вчиться сприймати аргументи й погляди інших, майже сторіччя психологи й педагоги виявляють стійкий інтерес до феномена дискусії. Окремих аспектів дискусійного навчання торкалися У. Глассер, С. Дем’янчук, Н. Михальчук та ін. У вітчизняній педагогіці теоретичні та практичні аспекти нових технологій навчання розроблено в науковому доробку В. Беспалька, О. Січкарук, О. Пометун, Н. Заячківської, Н. Мойсеюк, С. Пальчевського, О. Саган, О. Дженджеро, О. Пєхоти та ін.

Зокрема, українські методисти Н. Мойсеюк, С. Пальчевський переконані, що навчальні дискусії є методом стимулювання й мотивації навчально-пізнавальної діяльності учнів. До групи методів розвитку психічних функцій, творчих здібностей і особистісних якостей тих, хто навчається, відносять дискусію такі вчені, як С. Смирнов, І. Котова, Є. Шиянов [1].

О. Пометун вважає, що дискусія є ефективним способом у технологіях інтерактивного навчання. Дослідниця вважає, що дискусія, як інтерактивний метод викладання, може сприяти розвитку критичного мислення учнів, надаючи їм можливість захищати власні позиції та поглиблюючи їхнє розуміння обговорюваних питань [2].

Однак, попри наявні дослідження, в українській методичній літературі дискусія як метод навчання ще не до кінця розроблений: бракує конкретних пропозицій щодо організації та проведення різних форм дискусій, зокрема у вищій школі в підготовці майбутніх учителів початкової школи.

Формулювання цілей статті. Мета статті - актуалізувати проблему підготовки вчителів 3 новою парадигмою мислення, готових до інноваційної діяльності, розглянути використання технологій опрацювання дискусійних питань у підготовці майбутніх учителів початкової школи, надати організаційні й методичні поради щодо впровадження цієї групи інтерактивних технологій.

Виклад основного матеріалу. Аналіз наявного стану організації навчального процесу у вищих педагогічних закладах, академічної успішності та мотивації студентів дає підстави стверджувати, що традиційна освіта зі своїми стандартними формами, методами, засобами, змістом, цілями та завданнями не може сприяти інноваційності й осучасненню освіти, тому майбутні вчителі початкових класів не готові використовувати інтерактивні технології навчання у своїй педагогічній діяльності.

Для кращого розуміння деталей та специфіки використання інтерактивних методів, зокрема опрацювання дискусійних питань, необхідно надати майбутнім педагогам знання про 
особливості організації роботи, побудови інтерактивних занять та окремих елементів, запропонувати рекомендації щодо діяльності вчителя у створенні комфортних умов навчання та форм взаємного навчання [3].

Принагідно зауважимо, що найменш дослідженими серед груп інтерактивних технологій $є$ технології опрацювання дискусійних питань у початковій школі. Спричинено це тим, що багато викладачів 3ВО вважає, що дискусія поступається лекції, адже її важче організувати й провести. Проте переваги дискусії беззаперечні навіть у засвоєнні матеріалу студентами: є обмін інформацією, існування різних поглядів та припущень, здатність аналізувати та критикувати будь-яку точку зору, заохочувати учасників шукати спільну мову тощо [1].

Загальноприйнято вважати, що дискусія - це широке публічне обговорення якогось неоднозначного, суперечливого питання. Вона значною мірою сприяє розвитку критичного мислення, дає можливість визначити власну позицію, формує навички обстоювання свою думку, поглиблює знання з обговорюваної проблеми - і все це цілком відповідає завданням сучасної школи. Різні дослідники відносять дискусію не лише до методів навчання (способів роботи зі змістом навчального матеріалу), а й і до форм організації навчання, зокрема $є$ й такі, хто використовує дискусію як ігрову форму заняття, співробітництва, коли з обговорюваної проблеми ініціативно висловлюються всі учасники спільної діяльності [4].

Сучасна дидактика визнає велику освітню і виховну цінність дискусій. Вони вчать глибокого розуміння проблеми, самостійній позиції, оперування аргументами, критично мислити, зважати на думки інших, визнавати вдалі аргументи, краще розуміти іншого, сприяють уточненню власних переконань і формуванню власного погляду на світ.

Ознайомлення майбутніх учителів початкової школи з технологіями опрацювання дискусійних питань слід починати з організаційно-педагогічних засад, спільних для будь-яких різновидів дискусії:

- дискусія починається з постановки конкретного дискусійного питання (не містить однозначної відповіді, допускає різні варіанти розв'язання, зокрема протилежні);

- неприйнятний пошук відповіді на питання «хто правий, а хто - ні?»;

- у центрі уваги - ймовірний перебіг дискусійного обговорення (Що було б можливим за тим чи іншим збігом обставин? Що могло б відбуватись, якби...? Чи були альтернативні можливості, дії? тощо);

- висловлювання мають бути тільки в межах обговорюваної теми;

- викладач має виправляти помилки і неточності, яких припускаються дискутанти, та спонукати їх робити те саме;

- усі твердження учасників дискусії повинні супроводжуватись аргументацією, обгрунтуванням; на початкових етапах введення дискусій у навчальний процес педагог може допомагати питання на зразок «Які факти свідчать на користь твоєї думки?», «Як ти мислив, коли дійшов такого висновку?»;

- дискусія може закінчуватися як консенсусом (прийняттям узгодженого рішення), так і збереженням наявних розбіжностей між учасниками дискусії [5].

Щодо останнього твердження, то досить часто викладачі не вбачають цінності в дискусії, де сторони не досягли спільного рішення. Проте вона має низку переваг: учні ознайомлюються з альтернативними поглядами; прогнозують, які наслідки матимуть індивідуальні позиції і запропоновані рішення; використовують уміння захищати свою позицію; вчаться вислуховувати інших; отримують додаткові знання з теми.

На практиці деякі технології опрацювання дискусійних питань можуть справляти враження учнівських експромтів, які не потребують групової підготовки ні з боку вчителя, ні з боку учнів, проте таке враження хибне: за зовнішньою легкістю приховується грунтовна підготовча робота вчителя.

Майбутні вчителі початкової шкоди мають усвідомити, що, плануючи опрацювання дискусійного питання, педагогу слід враховувати кілька важливих моментів: час, необхідний для 
проведення дискусії, його узгодженість з іншими видами роботи під час навчального заняття; місце, яке має давати можливість здійснювати всі необхідні пересування учнів і створювати оптимальні умови для обговорення учнями проблеми і стеження за його перебігом решти учнів: матеріали, необхідні для роботи учнів та наочного подання іï результатів; письмові інструкції щодо способу виконання завдання; вміння учнів працювати в групі. Протягом усієї роботи груп учитель тримає в полі зору три основних моменти: мета, від якої під час дискусії не слід відхилятися; час, якого слід дотримуватися, щоб встигнути досягти визначеної мети; підсумки, які треба підбити, аби не втратити сенс самої дискусії [4].

Запорукою успішності дискусії є іiї чітка організація, яка досягається завдяки кільком чинникам.

По-перше, це планування дискусії. Складання плану дає змогу організувати як збирання учнями необхідної інформації, так і проведення самої дискусії.

По-друге, чітке дотримання правил ведення дискусії всіма ії̈ учасниками.

По-третє, обов’язковим є дотримання визначеного регламенту. Краще, коли час залишиться (його можна рівномірно розподілити наприкінці дискусії між учасниками), ніж його забракне на колективне обговорення на етапі підведення підсумків.

По-четверте, добре продумане й ефективно здійснене керівництво ходом дискусії з боку вчителя: надання учням часу на обміркування питань; утримання від нечітких запитань та запитань подвійного змісту; зміна напряму думок учнів у разі відхилення їх від основної теми і мети дискусії; пояснення висловлювань дітей системою уточнювальних запитань; запобігання надмірних узагальнень та ін. [5].

Розглянемо деякі з найбільш популярних технологій опрацювання дискусійних питань на уроках у початковій школі.

Цікавим методом, з якого, на нашу думку, варто почати роботу з упровадження технологій опрацювання дискусійних питань, є метод «Прес». Його використовують у ситуаціях, коли потрібно зайняти й чітко аргументувати визначену позицію з проблеми, що обговорюється. Метод навчає учнів виробляти й формулювати аргументи, висловлювати думки з дискусійного питання у виразній і стислій формі, переконувати інших.

Суть його полягає в покроковому проходженні чотирьох етапів (Рис. 1).

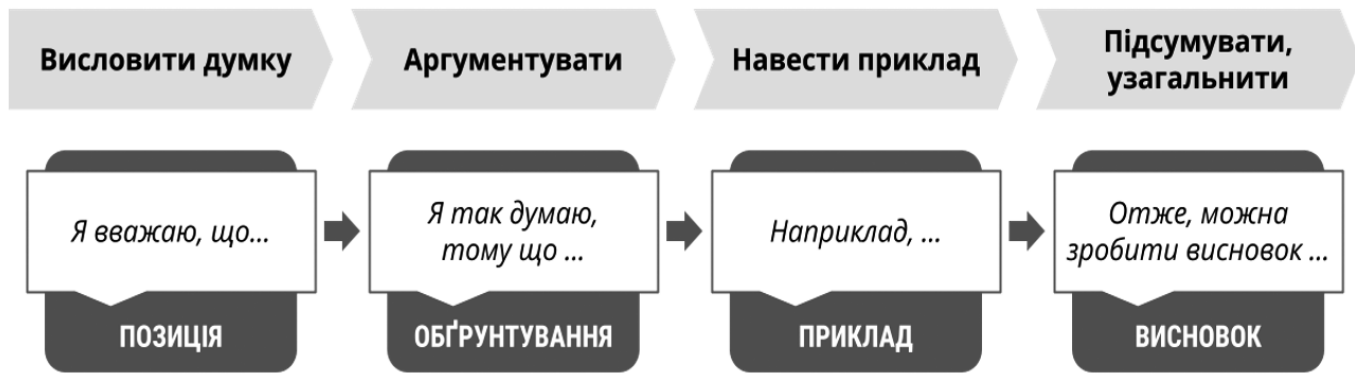

Рис. 1. Метод «Прес»

Прийоми методу «Прес» входять і до інших форм обговорення дискусійних питань, наприклад завдання «Займи позицію», яке можна використовувати різних етапах уроку: на початку для демонстрації розмаїття поглядів на проблему, що вивчатиметься, або після ознайомлення учнів з певною інформацією щодо проблеми й усвідомлення ними можливості по-різному її розв’язувати. Учні початкової школи люблять, коли їм пропонують підійти до однієї з табличок «ТАК», «НІ», «НЕ ЗНАЮ» й обгрунтувати вибір. Після того, як усі висловлять свої аргументи класу, дозволяється змінити точку зору й підійти до іншої таблички, обов'язково пояснивши причину свого переходу й назвавши найбільш переконливу ідею чи аргумент протилежної сторони [1]. 
Подібно до попередньої технології обговорення дискусійних питань за участі всіх присутніх можливим $€$ метод «Зміни позицію», завдяки використанню якого можна розвивати навички аргументування, активного слухання, прийняття точки зору іншої людини [2].

Попри нескладні на перший погляд вищезазначені прийоми і методи, варто зазначити, що застосування будь-яких елементів дискусії на уроках у початковій школі потребує ретельної попередньої роботи та знань, тому майбутній учитель повинен грунтовно оволодіти технологією підготовки й здійснення обговорення дискусійних питань.

Під час ознайомлення студентів з алгоритмом використання дискусій з навчальною метою рекомендуємо дотримуватись такої схеми:

I. Планування дискусії:

а) вибір теми (вона має бути проблемною, неоднозначною та актуальною, аби дискутанти могли висловити різні думки; також важливим $є$ наявність достатніх знань в учнів для обговорення заданої теми);

б) складання плану дискусії (його варто запропонувати заздалегідь, щоб учасники дискусії могли підготуватися до обговорення; якщо вже $є$ досвід участі присутніх у дискусіях, то план може бути представлений безпосередньо на початку обговорення);

в) розроблення чітких питань, створення сприятливої атмосфери.

II. Хід дискусії:

а) актуалізація основних правил участі в дискусії;

б) обговорення висунутих питань відповідно до плану.

III. Підведення підсумків дискусії:

а) коротко пояснити суть позицій, які були висловлені під час дискусії;

б) зазначити ефективність та правильність деяких позицій, відсутність переконливості в інших;

в) звернути увагу на точність формулювання дискутантами тез та чіткість і переконливість їхніх аргументів;

г) відзначити мовленнєву культуру дискутантів та проаналізувати стиль мовлення;

д) звернути увагу на толерантне ставлення дискутантів один до одного.

Варто зазначити, що управління дискусією не полягає в продовженні думки та винесенні власної позиції щодо кожного питання в дискусії. Практика показує, що найбільш ефективними $€$ відкриті запитання, які мають здатність стимулювати мислення, дивергентні чи оцінювальні за своїм змістом.

Дивергентні запитання полягають не в пошуку однієї правильної відповіді, а в тому, щоб заохотити до пошуку та творчого мислення. Оцінювальні запитання пов’язані з оцінюванням учасниками дискусії того чи іншого явища та висловленням власної точки зору [1].

Плануючи і проводячи дискусії в студентському середовищі, варто не забувати і про ознайомлення майбутніх учителів з конкретними темами для дискусійного обговорення в початкових класах. Прикладом цікавої для учнів молодшої школи теми дискусії може бути «Чи важливо виконувати обіцянки?». Діти залюбки висловлюють свою думку та аргументують їі. Наведемо приклади учнівських висловлювань:

1. Тримати слово - це важливо. Це означає, що на тебе можна покластися, тобі можна довіряти.

2. Так, бо людина, яка виконує обіцянки, стає впевненою, цілеспрямованою, починає поважати себе, її в усьому чекає успіх.

3. Важливо виконувати обіцянки: якщо пообіцяти, але не виконати, якщо сам не тримаєш слова, то перестаєш довіряти іншим людям.

Наведений приклад є елементом оцінювальної дискусії, оскільки основною ії метою є навчитися правильно формулювати власну думку та дискутувати.

Підготовка майбутніх учителів початкових класів до використання інтерактивних технологій опрацювання дискусійних питань базується на розвитку їхніх викладацьких здібностей, 
що відображається у здатності поєднувати абстрактне та конкретне, загальне та індивідуальне, раціональне та чуттєве.

Висновки та перспективи подальших досліджень. Отже, для підвищення якості методичної підготовки майбутнього фахівця актуальним $є$ впровадження в навчально-виховний процес закладів вищої педагогічної освіти інтерактивних технологій навчання. У цьому випадку значно підвищується особиста роль викладача - він виступає як лідер, організатор. Водночас проєктування і проведення заняття з елементами інтерактивних технологій потребують, перш за все, компетентності й обізнаності викладача, його вміння переглянути і перебудувати свою роботу.

Упровадження інтерактивних технологій навчання спонукає студентів займати активну позицію в засвоєнні знань і набутті досвіду, оволодівати мистецтвом швидко та ефективно розв'язувати навчально-методичні завдання у співпраці, удосконалювати культуру спілкування, розвивати критичне мислення.

Окремої уваги потребує вивчення застосування технологій опрацювання дискусійних питань на уроках у початковій школі, оскільки вони стимулюють пізнавальну діяльність і самостійність учнів, заохочують ініціативність учнів, розвивають творчу активність, дають змогу створити комфортні умови спілкування, залучити всіх учнів класу до активної взаємодії.

Як і кожна форма роботи з учнями на уроці, технології опрацювання дискусійних питань не досконалі, не є самоціллю в педагогічному процесі. Застосування різних форм дискусій, методів і прийомів дискусійного обговорення потребує подальших методичних пошуків. Зокрема, перспективними $є$ дослідження особливостей використання їх під час вивчення окремих тем та інтегрованих занять, взаємозв'язку з іншими інноваційними освітніми технологіями тощо.

\section{Використані джерела}

[1] О. Дженджеро, «Застосування інтерактивних технологій на уроках української мови в старшій школі (на прикладі опрацювання дискусійних питань)», Українська мова і література в школі, № 2 (112), c. 19-23, 2014.

[2] О. І. Пометун, Л.В. Пироженко Сучасний урок. Інтерактивні технології навчання. Київ, Україна: Видавництво А.С.К., 2004.

[3] Н.В. Стаднік «Формування готовності майбутніх учителів початкових класів до застосування інтерактивних технологій навчання», [Електронний ресурс]. Доступно: https://core.ac.uk/download/pdf/33691872. pdf. Дата звернення: 20.05.2021.

[4] Е.І. Федорчук «Підготовка студентів до використання сучасних педагогічних технологій». Педагогічний дискурс, 2, с. 175-178, 2007.

[5]. О. І. Пометун, Н. С. Побірченко, Г.І. Коберник, О. А. Комар, та Т. А. Торчинська, Інтерактивні технології: теорія та методика. Київ -Умань, Україна: АПН, 2008.

\section{References}

[1] Dzhendzhero O. «The use of interactive technologies in Ukrainian language lessons in high school (on the example of correcting discussion issues)». Ukrainian language and literature at school, 2 (112), 19-23, 2014. (in Ukrainian).

[2] Pometun O. I., Pirozhenko L. V (). A modern lesson. Interactive learning technologies. Kyiv, Ukraine: ASK Publishing House, 2004. (in Ukrainian).

[3] Stadnik N. V. (2016). Formation of readiness of future primary school teachers to use interactive learning technologies. [Electronic resource]/ Retrieved from https://core.ac.uk/download/pdf/33691872.pdf Date of application: 20.05.2021. (in Ukrainian).

[4] Fedorchuk E.I. Preparing students for the use of modern pedagogical technologies. Pedagogical Discourse, 2, 175-178, 2007. (in Ukrainian).

[5] Pometun O.I., Pobirchenko N. S., Kobernyk H. I., Komar O.A., Torchynska T.A. Interactive technologies: theory and methodology. Uman, Ukraine: APS, 2008. (in Ukrainian). 
Oksana Dzhendzhero, PhD (Pedagogy), Associate Professor, National University "Chernihiv Collegium” named after Taras Shevchenko, Chernihiv, Ukraine.

Svetlana Yushchenko, graduate student of the Faculty of Preschool, Primary Education and Art of the National University "Chernihiv Collegium” named after Taras Shevchenko, Chernihiv, Ukraine.

\section{USE OF TECHNOLOGIES OF DEBATING ISSUES IN THE TRAINING OF FUTURE PRIMARY SCHOOL TEACHERS}

Interactive learning technologies hold leading positions among the main innovations in the field of education. However, as practice shows, elementary school teachers are familiar only with certain elements of interactive learning technologies, the use of which in the primary school educational process is marked by fragmentary, episodic. This actualizes the need to include the relevant content in the subjectmethodological training of the future primary school teachers. After all, the primary school teacher schools must not only have knowledge of interactive technologies training, but also be able to apply them in practice. The methodology of using technologies for processing controversial issues requires a special study.

The study of the technology of elaboration of discussion issues devoted to the work of such scientists as N. Moiseyuk, S. Palchevsky, S. Smirnov, I. Kotova, E. Shiyanov, O. Pometun, S. Demyanchuk, N. Mikhalchuk and others. However, the analysis of discussions and their elaboration requires comprehensive view of the topic.

The subject of this article is to study and analyze the use of technology with the purpose of training of future primary school teachers. The aim is to consider and develop methods of discussion questions in primary school lessons.

The stages of the organization of the discussion and the role of the teacher in it were highlighted. The main methods of processing discussion questions that are relevant to use during lessons in primary school are analyzed. It was found that the educational environment requires the training of a teacher who is able to move away from traditional forms and methods of working with students and at the same time to accept new pedagogical experience, new technologies, forms and methods of work in their professional activities. The organizational and pedagogical conditions aimed at providing training for future teachers in the field of application of interactive technologies, in particular, technologies for processing discussion issues were identified.

Further studies require the use of technology to correct discussion issues in primary school lessons, that stimulate cognitive activity and independence of students, encourage student initiative, develop creative activity, allowing to create comfortable communication conditions, involving all students in active interaction.

Key words: communication; discussion; interactive technologies; forms of discussion; methods. 